\title{
Spirituele vorming om 'n missionale karakter in gemeentes in die praktyk te bewerkstellig
}

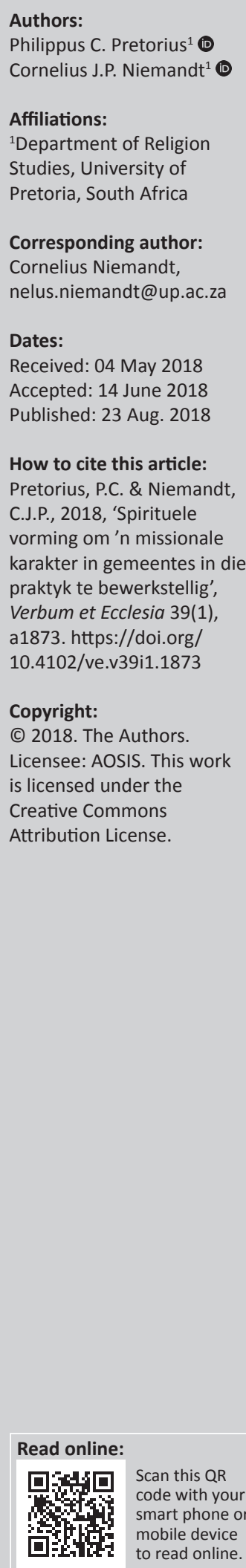

Spiritual formation to bring about a missional character in congregations in practice. This study applied literature review to focus on missional ecclesiology and, more specifically, on the important role and impact of spirituality in supporting a missional church. Although the research originated in reformed churches in South Africa, the reflection on the relation between the concept of missional church and a Christian spirituality, and the practical examples that illustrate such a missional spirituality, transcend the context and is applicable to most contexts. The conclusion of the research affirmed a Trinitarian approach to spirituality and the indispensable place of a missional spirituality for Christian congregations. A life in the Trinity forms and informs everyday life. It encourages disciples of Christ to participate in God's mission. There is no difference between Christian spirituality and missional spirituality. One of the key findings was the important role of habits: believers should change their habits in their everyday life in order to change their thoughts, and not the other way around. Practical examples of habits are as follows: systematic reading of God's Word; to see what God sees; kenosis shown through hospitality; faith discernment with other believers; associating the everyday normalities as spiritual; finding rest in God; and eating together.

Intradisciplinary and/or Interdisciplinary implications: This article was written from the perspective of mission studies. The contextual challenge was to emphasise the importance of habits in Christian spirituality, and the reciprocal relationship between spirituality and being a missional church. This article has challenged the culture of church-organised mission projects.

\section{Inleiding}

Hoe kan lidmate gemobiliseer word om meer missionaal te leef? Hoe gaan gemeentes gehelp word om meer missionaal te funksioneer? Hoe word lidmate se spiritualiteit gevorm deur gewoontes en rituele in hulle alledaagse lewe, en hoe voed dit ' $n$ missionale kultuur in die gemeente?

Hierdie navorsing geskied in die konteks van 'n groeiende bewussyn van die belang van missionale transformasie. In hierdie trant, skryf Jackson (2016): 'Missionale transformasie se doel is nie om gemeentes te transformeer om uitreikprojekte te hê nie. Dit is gemik op innerlike transformasie sodat lidmate besef ons is almal sendelinge.'

Niemandt (2014:7) verwys na tradisionele Afrikaanse kerke (histories gesproke veral die Nederduitse Gereformeerde Kerk, die Nederduitsch Hervormde Kerk in Afrika en die Gereformeerde Kerke in Suid-Afrika), wat almal deel is van 'n 'missionale Renaissance'. ${ }^{1}$ Van Rensburg (2018:150-196) beskryf die missionale transformasie in die Apostoliese Geloofsending van Suid-Afrika. Mouton (2017:158) stel dat die missionale beweging vrugbare grond in Suid-Afrika gevind het. Daar het inderdaad 'n nuwe missionale era vir die kerk aangebreek (Keifert 2017:266).

Daar bestaan ook 'n wyer en groeiende ekumeniese konsensus oor hierdie saak (Niemandt 2014:7). Die fokus van hierdie konsensus is dat die kerk se wese en sy rol in die wêreld direk uit die drie-enige God se aard en wese gevorm word. Dit beteken ook dat volgelinge (dissipels) van Christus al meer soos Christus moet word, gestuur is soos Christus gestuur is, en hulleself moet prysgee soos Hy gedoen het (Jackson 2016; Keifert 2017:265). Die implikasies hiervan strek na gemeentes en lidmate se geloofsgewoontes en sluit sake in soos om vars uitdrukkings van geloofsgemeenskappe te skep waar die hele kerklike lewe op 'n missionale bestaan fokus (Janse van Rensburg 2016).

1.Die ASM (Algemene Sinodale Moderamen) van die NG Kerk het aan die einde van 2015 'missionale transformasie' as sy eerste prioriteit vir die NG Kerk geïdentifiseer. 
Gemeentes en individuele gelowiges vra na die wil van die Here en breek deur eeue-oue vasgestelde gewoontes ter wille van gehoorsaamheid aan hulle roeping (Janse van Rensburg 2016). Gelowiges se verhoudings moet ook al meer soos die onderlinge verhoudings tussen die drie Persone van die Drieeenheid word. Daar word gepraat van deelname aan die lewe en innerlike verhouding van die Triniteit. Keifert (2017:268) stel dit soos volg: 'we've got an understanding of the church, being caught up into the life of the Trinity'. Uiteindelik moet gelowiges die evangelie beliggaam in wat hulle is en hoe hulle leef sodat die wêreld dit kan sien (Jackson 2016).

Die missionale beweging is gewortel in die missio Dei en die (her)ontdekking dat die lewende God teenwoordig en aktief in die wêreld is (Burger 2017:27). Die drie-enige God is die sturende God. God stuur sy Seun na die wêreld. God stuur ook sy Heilige Gees na sy volgelinge om van hulle 'n beweging in die wêreld te maak. Elke gelowige word só deel van God se sending na die wêreld. Die kerk is tegelykertyd 'n produk van en deelnemer aan God se sending.

Die doel van hierdie navorsing is om praktiese riglyne te formuleer wat gemeenteleiers en lidmate van gemeentes kan help om 'n missionale karakter te kweek deur die ontwikkeling van 'n missionale spiritualiteit. Die onderliggende oortuiging is dat aandag aan missionale spiritualiteit tot missionale vorming en transformasie bydra.

Ter inleiding word aandag gegee aan insigte wat verwerf is vanuit ' $n$ literatuurstudie oor hoe ' $n$ missionale spiritualiteit in die praktyk gekweek kan word. Daarna word 'n oorsig gegee oor sewe praktiese gebruike wat in gemeentes geïmplementeer kan word wat kan help om lidmate se missionale spiritualiteit en karakter te aktiveer. Die bedoeling is dat gemeenteleiers hierdie voorstelle deel van hulle eie lewe maak en lidmate bemagtig om dit deel van hulle spiritualiteit te maak.

\section{Die vorming van 'n missionale spiritualiteit in die praktyk}

Marais (2017:375) maak 'n sterk saak vir die belang van missionale vorming en beskryf dit as die bewustelike gemeenskaplike proses waarbinne die verhouding met God groei en waardeur volgelinge al meer Christusgelykvormig word deur die krag van die Heilige Gees. Dit is die bron van energie wat deelname aan die sending van God moontlik maak. Die Wêreldraad van Kerke (World Council of Churches [WCC] 2013:52) argumenteer in dieselfde trant en stel: 'Spirituality gives deepest meaning to our lives and motivates our actions.'

Dit is nodig om die aard en wese van Christelike spiritualiteit kortliks te omskryf. Die begrip spiritualiteit kan verwys na die diepste waardes en betekenis wat aan die lewe geheg word. Spiritualiteit kan verwys na ideale wat kan help om mense se volle potensiaal te verwesenlik (Sheldrake 2007:2). Principe (1983:139) omskryf hierdie aspek van spiritualitiet soos volg: 'Spirituality ... points to those aspects of a person living a faith or commitment that concern his or her striving to attain the highest ideal or goal.' Peterson (2005:29) sluit hierby aan: 'Living, living fully and well, is at the heart of all serious spirituality.' Howard (2008:16) is meer gefokus in sy benadering tot spiritualiteit wanneer hy sê dat spiritualiteit op mense se interaksies met die transendente of Goddelike fokus. Hierdie twee benaderings vul mekaar aan indien aanvaar word dat mense se interaksie met God juis aanleiding gee tot 'living fully and well'.

Binne hierdie breë omskrywing van spiritualiteit is dit nodig om Christelike spiritualiteit nader te omskryf. Principe (1983:135) omskryf Christelike spiritualiteit as 'life in the Spirit as brothers and sisters of Jesus Christ and daugthers and sons of the Father'. Hierdie omskrywing van Christelike spiritualiteit beklemtoon die trinitariese fundering van Christelike spiritualiteit sowel as die gemeenskaplike aard daarvan. Later brei Principe (1983:139) hierdie trinitariese fundering uit: 'For a Christian this [spirituality] would mean an ever more intense union with the Father through Christ by living in the Spirit.'

Christelike spiritualiteit het daarom alles te doen met transformasie en missionaliteit. Sheldrake (2007) stel dit soos volg:

... it is nevertheless possible to say that, taken as a whole, the scriptural foundations of Christian spirituality suggest a way of transformation towards fullness of life in God and at the same time a way of mission through following the way of Jesus and by means of the power of God's indwelling Spirit. Transformation and mission are therefore key ideas for understanding Christian spirituality. (p. 33)

Willard (1996:1) stel die belangrike vraag oor transformasie: Hoe verander mense? Indien ons vir die gemiddelde kerkganger gaan vra hoe word ons mense van liefde, geluk en vrede, wat sal die kerkganger antwoord? Cray (2009:82) sluit aan en vra: 'Hoe kan die kerk beter antwoord op die roeping van Jesus om na al die nasies te gaan en dissipels te maak?'

Die antwoord lê in missionale transformasie. Hierdie diep transformasie na 'n missionale bestaan vereis dat elke lidmaat moet besef dat hulle gestuur is om binne hulle konteks mense se lewens te help verander (Ford \& Hirsch 2011:63). Dit is nie net ' $n$ uitgesoekte groep lede van die gemeenskap van gelowiges wat deur God gestuur word nie. Christene soos onderwysers, dokters, ingenieurs, boere, ensvoorts is almal gestuurdes. Missionale transformasie is in missionale vorming ingebed en dus missionale spiritualiteit. Dr. W.C. de Klerk bevestig in 'n epos van 7 Junie 2018 dat missionale kerkwees op die fondasie van 'n omvattende en lewenskragtige Christelike spiritualiteit gebou moet word. Spiritualiteit en missionalteit is ' $n$ identiese tweeling - met spiritualiteit die eersgeborene! Sonder lewenskragtige spiritualiteit, sal missionale kerkwees nie volhoubaar wees nie.

Dit beteken dat die locus van die kerk se sendingwerk verskuif na die plaaslike gemeenskap. Die 'nabye konteks' of die buurt (Roxburgh 2011) is net so' $n$ belangrike sendingveld 
soos wanneer iemand in 'n ander land sendingswerk gaan doen. Sparks, Soerens en Friesen (2014:48) gebruik die term geloofwaardige teenwoordigheid (faithful presence) en stel dit soos volg: 'Faithful presence invites you to act on the belief that God is giving you what you need to be formed as disciples within your location.'

Missionale spiritualiteit bring die alledaagse leefwêreld in fokus en motiveer lidmate om aktief by hierdie wêreld betrokke te raak en te dien. Die beste hoop vir die kerk is wanneer elke lidmaat hom- of haarself individueel begin sien as iemand wat deur God die wêreld ingestuur word (Ford \& Hirsch 2011:64; Hendriks 2007:1004). Niemandt (2013:174) stel: "n Missionale lewe is om 'n dissipel te wees, en dit gaan hand aan hand met spiritualiteit.' ' $n$ Missionale spiritualiteit is 'n geestelike bewussyn van God se teenwoordigheid en 'n lewe in die Triniteit. Daar is eintlik ook nie 'n missionale spiritualiteit wat verskil van 'n 'gewone' spiritualiteit nie. Alle vorms van Christelike spiritualiteit is ten diepste missionale spiritualiteit (Niemandt 2013:175). Alle spiritualiteit is inherent ook trinitariese spiritualiteit. Die verhouding is deur God die Vader geïnisieer, deur die werk van Jesus Christus bevestig, en word deur die Heilige Gees toegepas (Venter 2015:3).

'n Lewe 'in die Triniteit' kan nie anders as om missionaal van karakter te wees nie. Elke lidmaat, in 'n amp bevestig of nie, is gestuurdes - soos dit in die karakter van die Triniteit lê. Die Vader stuur die Seun, die Seun stuur die Heilige Gees, en die Heilige Gees stuur elke gelowige. Die wese van God se karakter is missionaal en gelowiges kan nie anders as om aan te sluit by die drie-enige God se doel en roeping vir die kerk nie. Hastings (2012:loc.840) stel dit baie duidelik: die deelname aan die sending van die Triniteit is die enigste manier hoe 11 dissipels agter geslote deure die wêreld kon transformeer. Die kerk kan alleenlik die evangelie in die post-moderne wêreld uitdra wanneer dit vanuit die storie van die drie-enige God geïnterpreteer word (Hastings 2012:loc.840). Die grootste wonder van die Christelike evangelie is dat die Triniteit dit vir gelowiges moontlik maak om deel van die innerlike hegte verhouding tussen Vader, Seun en Gees te wees. Dit bring nuwe insigte oor die kerk in die wêreld. Die Triniteit dring tot aksie om dit wat in God se hart leef, duidelik te maak aan die wêreld. Dit kan slegs gedoen word wanneer daar vanuit die verhouding met die drie-enige God oorgegaan word na gewoontes en praktyke wat in die alledaagse lewe toegepas word en sodoende God sigbaar in die wêreld te maak.

Missionale spiritualiteit het dus te doen met geestelike vorming. Dit is 'n doelbewuste gemeenskaplike proses waarin gelowiges in hulle verhouding met God groei en meer en meer deur die krag van die Heilige Gees navolgers van Christus word. Egte missionale spiritualiteit gaan ten diepste oor die ontdekking van God se ritme en gang, en die vermoë om in pas met daardie ritmes te lewe.

Smith (2016:loc.98) gee in sy teologie baie aandag aan missionale spiritualiteit. Hy argumenteer dat elke gelowige se diepste hartsbegeertes en dit waarvoor ' $n$ mens lief is, in lyn moet wees met God se diepste hartsbegeertes en waarvoor God lief is. God wil hê gelowiges moet najaag wat Hy najaag, begeer wat Hy begeer en 'n wêreld skep soos God dit herskep. Smith (2016:loc.98) stel dit so: 'To be a disciple of Jesus is to enroll in die school of charity.' Van die eerste gemeentes waarPaulusgewerkhet, hetgestreefomgeloofsgemeenskappe te wees wat nie net glo in die evangeliese boodskap nie, maar wat die evangeliese boodskap wórd (leef). Deur dit te doen, is hulle gedring om deel te neem aan die lewe en sending van God (Gornman 2015:loc.94). Paulus se nuwe lewe het begin toe sy Godsbeeld omgekeer is. As gelowiges die bevrydende krag van God se boodskap wil ervaar, moet hulle bereid wees om uit ou gewoontes na nuwe gewoontes beweeg te word (Nicol 2013).

Kerke kan wonderlike missionale visie-stellings en uitstekende programme in plek hê, maar indien individuele lidmate nie toegewyd is om hulle daaglikse lewens as koninkryksgedrewe gestuurdes te lei nie, sal die programme van die kerk as geheel nooit hulle koninkryksplan vervul nie. Dit is onmoontlik om 'n missionale kerk te wees wanneer lidmate nie missionaal dink en leef nie. 'n Missionale leefwyse gaan nie oor programme van die kerk wat gefinansier moet word as iets wat 'daar ver' moet plaasvind nie (Ford \& Hirsch 2011:65). Janse van Rensburg (2016) beklemtoon dat nuwe geloofsgewoontes aangeleer moet word:

Ons gaan nie ander resultate behaal deur net dieselfde te bly doen nie. Ons het nuwe gewoontes nodig wat ons refleksie oor die Woord en die teenwoordigheid van God in ons lewe versterk. (n.p.)

Op persoonlike vlakke moet ruimtes geskep word om bewustelik in die teenwoordigheid van die drie-enige God te leef. Sonder 'n eerstehandse getuienis oor wat God in die lewe van elke gelowige kom doen, sal die missionale beweging nie momentum opbou of behou nie (Janse van Rensburg 2016). Die kerk is immers niks minder as ' $n$ lewe in die Triniteit nie (Niemandt 2016:88).

In plaas daarvan dat denke moet verander sodat nuwe gewoontes aangeleer word, moet gewoontes verander sodat denke vernuwe kan word. Daar word dus op die verskil tussen kernwaarhede en kerngebruike gelet (Hirsch \& Altclass 2009:loc.261). Hirsch en Altclass (2009) stel dit soos volg:

First, given our current state of knowledge and how we gain it, we have to shift from trying to think our way into a new way of acting to the process of acting our way into a new way of thinking. (loc.261)

Die kern van die argument is dat denke nie tot gewoontes lei nie, maar dat gewoontes tot nuwe denke en lewe lei. Sukses sal nie bloot behaal word deur net mense met woorde te leer wat dissipelskap is nie. Dit moet geleef word.

Jesus het sy dissipels geroep en hulle geleer. Hulle vorming is deur lewenswerklike situasies en alledaagse uitdagings gebeitel. Hierdie proses dui 'n weg saam met Jesus aan en nooi die kerk ook uit om saam op weg na 'n nuwe soort dissipelskap te wees. Hierdie pad lei die onbekende in en verg 'n spiritualiteit van 'op weg wees' saam met die onvoorspelbare Gees (Niemandt 2016:97). 
Aanbidding en gewoontes moet gewortel wees in die Heilige Gees se uitnodiging om in ' $n$ diepe verhouding met die Drie-eenheid te leef (Smith 2013:loc.3247). Vanuit hierdie waarheid groei nuwe gewoontes en gebruike wat 'n missionale spiritualiteit aktiveer.

\section{Spirituele dissipline in die alledaagse gewoontes}

Die klem is op die aankweek van gewoontes en praktyke. Niemandt (2016:86) verwys na reflective rituals [nadenkende rituele] wat gelowiges help en 'n kreatiewe invalshoek skep om missionale transformasie te laat bloei. Transformasie beteken nie net om as 'n gemeente harder te probeer om missionaal te lewe nie, maar om op gewoonte-inoefening te fokus (Ortberg 2002:42-43). Burns (2017:359) maak juis die punt dat die vormende aard van praktiese geloofsgewoontes 'n belangrike rol in dissipelskap speel.

Kreminski (2014:142) onderskei vier dimensies van missionale praktyke, naamlik inkarnasie, pneumatologie, Trinitaries en kenoties. Hy argumenteer dat aandag hieraan die weg baan vir missionale vorming en stel voor dat hierdie praktyke as gewoontes aangeleer word om sodoende 'n gemeente missionaal te rig. Hierdie praktyke skep die konteks vir die Heilige Gees om 'n transformasieproses aan die gang te sit.

Spiritualiteit is nie net ' $\mathrm{n}$ uitdrukking van leerstellings nie. Teologie is die dienskneg en nie die meester van Christelike ervaring nie (Venter 2015:2). Dit veronderstel 'n skuif vanaf lering (kognitiewe verstaan) na die toepassing van die lering. Die oortuiging is dat dit slegs kan gebeur wanneer lidmate gemobiliseer word om nuwe gewoontes en praktyke in hulle lewens te begin inoefen. Uiteindelik sal hierdie missionale praktyke (gewoontes) lidmate ook help om te onderskei waar hulle by God se missionale plan vir die wêreld kan aansluit. Hierdie praktyke word soos volg omskryf (Kreminski 2014):

Missional practices are explained as regular activities that Christians do together in order to allow the Holy Spirit to shape them into missional Christians who are on God's mission in the world to continue his work of redemption. (p. 144)

Die volgende praktiese gewoontes word voorgestel:

\section{Spirituele dissipline 1: Sistematiese lees van die Bybel}

Die eerste dissipline verwys na 'n gereelde en geprogrammeerde lees van die Bybel. Burns (2017:355) noem dit 'n heilige gewoonte en praat van wandel in die Woord. 'n Gelowige word aangeraai om byvoorbeeld twee keer per week in 'n publieke plek te gaan sit en die Woord te lees. Die Evangelies kan as voorbeeldtekste hiervoor gebruik word.

Hierdie gewoonte stel die deelnemer in staat om raak te sien wat God besig is om in die omgewing te doen. Die lees van die Woord moet eintlik deur missio Divina [goddelike sending] geskied met die oog op die missionale spiritualiteit wat in elke gelowige gekweek word. Die praktyk behels dat 'n gekose Skrifgedeelte stadig deurgelees word en dat die deelnemer wag om God se stem te hoor om sodoende bewus te raak van wat God deur die gedeelte wil sê. Daarna moet die teks van toepassing gemaak word op die wêreld wat op daardie oomblik sigbaar is (Kreminski 2014:142). Dit bewerkstellig ook die noodsaaklike beweging om die konteks in die lig van die Skrif te sien en om die Bybelgedeelte op die beskikbare konteks toe te pas. Dit vorm lidmate om die aktiwiteite van die lewende God in die geloofsgemeenskap en gemeenskap te onderskei (Burns 2017:354). Dit kan byvoorbeeld in 'n park of 'n koffiewinkel of êrens tussen mense plaasvind. ' $\mathrm{n}$ Besondere vrugbare gewoonte is om hierdie praktyk in plekke van sigbare nood te beoefen. So kan 'n informele nedersetting dien as 'n plek om die Woord beter teverstaan en om dalkselfs iets van gemarginaliseerdes se ervaring van die lewe te hoor.

Uiteindelik is die doel dat gelowiges leer om nie net na binne te kyk nie - die lees van die Woord word 'n venster op die wêreld om God in die alledaagse en veral in die nood van mense raak te sien: 'Community and individual formation are inseparable' (Burns 2017:359).

\section{Spirituele dissipline 2: Om te sien wat God sien}

'n Praktiese gewoonte wat hierby aansluit, is om met oop oë te bid. Die bedoeling is om die alledaagse in verband met ' $n$ lewe in die Triniteit te bring. Gelowiges word aangemoedig om die alledaagse as ontmoetingsplek raak te sien. Dit vra 'n bewussyn van die oomblik en plek. Dit vra om oop te wees vir alles wat in gebed sigbaar gemaak kan word.

Hierdie gewoonte geld nie net vir die tye waar die Woord in 'n publieke plek gelees word nie, maar ook vir tye deur die dag waar daar in die alledaagse gang en uitspeel van die lewe in gebed tot die Here genader word (Kreminski 2014:145).

Nog 'n voorbeeld van hierdie gewoonte is om in ' $n$ publieke plek te gaan sit en net vir die Here te vra: 'Laat my sien wat U sien' (Kreminski 2014:145). Die kern van hierdie gewoonte is die bewuswording van waar die Here in die wêreld rondom elke gelowige aan die werk is. Dit poog om die wêreld te sien soos God die wêreld sien. In die raamwerkdokument van die NG Kerk (2013) word die opdrag verduidelik:

Die eerste stap op die pad van 'n missionale gemeente is om te onderskei. Die kerk kan sy roeping nie onderskei sonder om deurentyd bewus te wees van God wat in die wêreld en in elke konteks aan die werk is nie. Ons vreugde lê daarin om dit te ontdek. (p. 8)

Dit stem ooreen met wat Burns (2017:355-356) 'wandel in die wêreld' noem. Die teologiese rasionaal is die oortuiging dat God aktief in die wêreld aan die werk is: 'We begin with a focus on God as the acting subject, dedicated to attentiveness to his activity' (Burns 2017:362). 


\section{Spirituele dissipline 3: Kenosis uitgebeeld in gasvryheid}

Die term kenosis word soos volg deur die NG Kerk se raamwerkdokument omskryf: 'Kenosis is die teenoorgestelde as selfhandhawing en self-vervulling.' Kenosis, soos gesien word in Filippense 2:5-11, beteken selfprysgawe en opoffering. Hierdie terme wys op die wese van die lewe in die Triniteit: God die Vader gee sy eie Seun prys ter wille van sy liefde vir die wêreld. Die Seun is gehoorsaam aan sy sending na die wêreld en gee sy eie lewe prys vir versoening nadat Hy eers Homself ook prysgegee het om 'n slaaf in die wêreld te word om die hele mensdom te kom dien. Die Heilige Gees kommunikeer aan elkeen die opoffering en selfprysgawe van die Vader en die Seun. Kenosis is dus om jouself leeg te maak en kwesbaar te stel voor ander mense. Kenosis is in die hart van die gestuurde teologie, want dit lê in die hart van God self (Nederduitse Gereformeerde Kerk [NGK] 2013). Dit sluit weer duidelik aan by die vorige punte oor 'n missionale spiritualiteit wat in 'n trinitariese spiritualiteit gewortel is. Marais (2017:376) maak juis 'n sterk saak uit dat kenosis nie net oor Christus is nie, maar dat die kenotiese Seun die kenotiese Vader openbaar, en dat die kenotiese Christus 'n beeld van die kenotiese God is.

'n Praktiese geloofsgewoonte is om lidmate uit te daag om 'n radikale gasvryheid te betoon - gasvryheid tesame met 'n missionale ingesteldheid van selfprysgawe om te wys dat die Christelike lewenswandel een van diensbaarheid is. Dit is dade van goedhartigheid en omgee, selfs teenoor mense wat jou ontstel en kwaad maak (Niemandt 2016:95). Deur hierdie gewoonte word lidmate uitgedaag om te kyk waar daar in hulle omgewing mense met nood is, en dan ' $n$ daad van gasvryheid aan die gemarginaliseerdes te betoon. Voorbeelde hiervan is om vir iemand wat haweloos is ' $n$ koppie koffie te maak, of om met die persoon wat by die werk uitgestoot word 'n gesprek aan te knoop. Dit kan moeiliker take wees wat lidmate uit hulle gemaksones haal soos om ' $n$ hawelose persoon vir ete by die huis te nooi, of dit kan ' $n$ minder moeilike taak wees soos om vir 'n kollega iets te drinke aan te bied (Kreminski 2014:146-147). Hierdie kenosis wys aan die wêreld dat Christus daar is vir die gemarginaliseerdes en verstotenes (Kreminski 2014:147). Gasvryheid skep die bewussyn dat Christus teenwoordig is - die Gees werk en het die potensiaal om geloofsgemeenskappe te transformeer (Burns 2017:368).

\section{Spirituele dissipline 4: Geloofsonderskeiding saam met ander gelowiges}

Onderskeiding is eintlik die heel eerste daad van sending (Niemandt 2016:90). Die wese en identiteit van die kerk is dat dit die gemeenskap van volgelinge is wat deur die Gees geroep is op 'n reis van geloofsonderskeiding. Die kerk is altyd aan die beweeg (Niemandt 2013:70). Die plek op hierdie reis saam met die lewende drie-enige God word deur geloofsonderskeiding verstaan. Dit is opvallend hoe belangrik die tema van mense wat 'op reis is' in die Nuwe Testament is. Die geskiedenis van die eerste kerk neem die vorm aan van op reis wees na die uithoeke van die aarde. Jesus beskryf Homself as die weg, die waarheid en die lewe. Dit is juis die nuwe verstaan van die kerk as deelnemers aan God se sending wat die die begrip kerk wegstuur wegstuur van die kerkgebou as die plek waar kerk gebeur, na die bewussyn (onderskeiding) van grense wat oorgesteek moet word na die wêreld (Niemandt 2013:71). Op so 'n manier nooi die kerk die wêreld 'daar buite' saam op hierdie reis.

'n Missionale spiritualiteit bou op God se nabyheid, betrokkenheid en teenwoordigheid in die wêreld. 'n Missionale spiritualiteit word deur die Gees van God gelei om te onderskei waar Hy teenwoordig en aan die werk is. Sulke veranderings lei altyd tot een of ander vorm van missionale aksie in die wêreld. Daarom is geloofsonderskeiding een van die belangrikste en mees beslissende stappe op die reis van missionale vernuwing (Niemandt 2013:72-73).

Om dit prakties toe te pas en 'n gewoonte te kweek, kan die volgende vrae hier gevra word:

- Wat is God besig om te doen? Die gemeente en lidmaat is veronderstel om te vra waarmee die Heilige Gees in die wêreld (in die konteks) besig is.

- Wat wil God doen? Elke lidmaat behoort ook te vra wat God in sy wêreld wil doen. Hoe lyk dit as God stukkende verhoudings wil herstel, vernuwing wil bring en versoening bewerkstellig? Hoe sluit ek as lidmaat en gemeente aan by dit wat God wil doen (Niemandt 2013:73)?

Dit is nodig dat gelowiges wat 'n missionale spiritualiteit kweek in die gewoonte kom om weekliks in 'n kleingroep bymekaar te kom. Dit help lidmate om in die geloof te onderskei waarmee hulle en God op die oomblik besig is. Dit help alle betrokkenes om in hulle missionale vorming te groei. Gelowiges moet verkieslik weekliks bymekaarkom en deel wat die afgelope week in hulle lewens gebeur het. Dis veral nodig om na mekaar te luister oor wat God alles die afgelope week in almal se lewens gedoen het. Dit is hier waar gelowiges ook by mekaar leer, mekaar versterk en bemoedig indien dit nie goed gaan met 'n lid in die groep nie. In hierdie groepe kan daar geoefen word om in die Woord en daarna in die wêreld te wandel.

Die geestelike reis na 'n missionale gemeente is nie 'n individuele saak nie. Die geloofsgemeenskap moet die karakter van die Drie-eenheid uitbeeld en onderlinge gemeenskap en innige verhoudings koester (Kreminski 2014:149). Burns (2017:358) is oortuig dat alle geloofsgewoontes eintlik kommunaal in wese is: 'An ecclesial practice involves a complex tradition of interactions among many people sustained over a long period of time.' Niemandt (2016:94) praat van 'n 'perichoretic notion of relationships' - 'n ingesteldheid wat diversiteit en pluraliteitkoester,enterselfdertydeenheideninterafhanklikheid najaag. 'n Missionale spiritualiteit is verhoudingsgedrewe en in die smeltkroes van liefde gevorm. 


\section{Spirituele dissipline 5: Koppel die alledaagse met die geestelike}

Geestelike vorming kan nie volhoubaar wees indien dit tot slegs een byeenkoms 'n week beperk is nie. Smith (2009) praat van gewoontes anderkant Sondag wat baie belangrik is vir die inoefening van ' $n$ missionale spiritualiteit. Smith (2009:223) leer dat die geestelike gebruike op Sondae beoefen word en die res die tyd gaan die lewe bloot aan soos gewoon. Hy wys ook daarop dat die geestelike transformasie nie net in die erediens plaasvind nie, maar moet ook verder gaan in die lewe van 'n gelowige (Smith 2009:207).

Harrison (2017:400) beklemtoon dat die kerklike lewe en liturgie nie in private enklawes moet skuil waar die kerk van die wêreld probeer ontsnap nie: 'but rather to worship in the world and be orientated towards the created order as that which is God's loving concern and where God is active'.

Hoekom is dit dat so baie lidmate weekliks eredienste bywoon, maar daar is nie daadwerklike verandering in hulle lewens nie? Smith (2009:208) is ook daarvan bewus dat die transformerende krag van die Heilige Gees in die erediens nooit onderskat moet word nie. Dit is dus nie al wat belangrik is in die lewe van 'n missionaal-gedrewe kerk nie. Dit moet ook 'gewoontes anderkant Sondag' wees wat ingeoefen word in 'n gelowige se lewe vir die koninkryk van God (Smith 2009:211). Dit kan die beste verduidelik word as aanbiddingsgeleenthede waar saam met lidmate gedeel kan word en wat vanuit die Sondagliturgie na die liturgie van die alledaagse lewe uitvloei.

Hierdie gewoonte om die alledaagse met die geestelike te koppel, moet weekliks in 'n byeenkoms van gelowiges buite die erediens plaasvind waar almal in 'n kleingroep saam gesels en deel wat in elkeen se geestelike lewe aan die gebeur is. Dit is om die liturgie van die erediens verder te neem en om dit deur die week deel te maak van die alledaagse lewe. Zscheile (2012:20) praat van die curriculum van die wêreld. Deelnemers aan God se sending is, soos God, gerig op die wêreld in die wete dat God juis daar raakgeloop word. So word gelowiges meer bewus van dit waarmee God in die lewe en wêreld besig is. Smith (2009:211-213) stel voor dat die gewoonte moet bestaan om weekliks saam met gelowiges brood te breek en om die Woord vergader moet word om sodoende mekaar op die geloofspad te ondersteun. Dit moet 'n omgewing wees waar gelowiges met mekaar oor geloof en die uitdagings van die alledaagse lewe gesels. Sodoende word groeplede geleer om meer missionaal op die wêreld ingestel te wees - hetsy by die werk, sosiale geleenthede of 'n sportbyeenkoms. Ortberg (2002:201-202) meen ook dat die alledaagse lewe so ingerig moet word dat alles wat gedoen word van dissipelskap spreek. Elke aksie moet deel van 'n lewe voor God wees.

Missionale spiritualiteit beteken elke gewone daad word gesien as iets wat gebruik kan word in die Here se werk. Ortberg (2002:202) verwys na alledaagse sake soos motor bestuur, TV kyk en radio luister, en stel dat alles deel van 'n lewe voor God is.

\section{Spirituele dissipline 6: 'n Gewoonte van rus by God}

'You must ruthlessly eliminate hurry from your life' (Ortberg 2002:77). Gejaagdheid bedreig 'n dieper geestelike lewe. Een van die grootste foute wat gelowiges maak, is om te dink dat deur meer gejaagd te wees, hulle meer tyd sal hê: 'Hurry will keep us consumed by "the cares and riches and pleasures of life" as Jesus put it, and prevent his way from taking root in our hearts' (Ortberg 2002:78-79).

Niemandt (2016:94) verwys na die belangrikheid van stilte. Hierdie soort stilte is om jou af te sonder sodat jy weer ontvanklik vir God se teenwoordigheid kan raak en sodoende weer jou identiteit in Christus herstel. Dit is om die 'gedagtegeraas' wat binne 'n mens woed te verstaan en tot rus te bring (sien ook Nicol 2016:47). Daar word uit Jesus se voorbeeld gesien hoe Hy Homself gereeld van die skares en aktiwiteite onttrek het. Hy het ook sy dissipels dieselfde beginsel geleer. Natuurlik mag gelowiges ook besig wees. Daar mag net nie tye wees wat gelowiges so besig raak met die dinge van die wêreld dat daar vergeet word wat die Here eis nie. Transformasie en verdieping in die Here kom altyd stadig en daar is nie 'n kitsoplossing daarvoor nie (Ortberg 2002:81). Daar word ook gevind dat indien alles in die lewe gejaagd is, sekere waarhede wat die Here leer verlore gaan soos die vermoë om lief te hê. Wanneer alles in die lewe oor optimale tydsbesteding gaan, word mense wat liefde nodig het, misgekyk. Om 'n missionale spiritualiteit te vorm, moet liefde aan die naaste betoon word. Om dit te laat gebeur, is tyd en energie nodig. Vol programme verg aandag (Ortberg 2002:81). Te vol programme bedreig rus en vrede by God.

\section{Die noodsaaklikheid van afsondering en rus by God}

Tye van stilte en rus gaan oor die vestiging van ' $n$ nuwe lewensritme. Hierdie nuwe lewensritme help ook met die paradigmaskuif, naamlik dat jou geestelike lewe en jou regte lewe nie geskei is nie, maar dieselfde is. 'Ons is almal daaraan gewoond om oor die kerk en die wêreld te praat asof dit twee heeltemal verskillende werklikhede is' (Niemandt 2007:72). Tydperke van afsondering is nodig om te rus en weer perspektief te kry. Afsondering help om sin te maak uit alles. Hierdie dimensie van die vorming van harte weerspieël iets van 'n leier se bewustelike kweek van 'n verhouding met God (McNeal 2009:xiii).

Jesus Christus is die voorbeeld van afsondering. Hy het gereeld tyd gemaak om eenkant in gebed tot die Vader te nader. Hierdie gewoonte moet in die daaglikse roetine ingewerk word.

Christene het dissiplines gevorm wat inwaartsgekeer en selfgerig is, eerder as om na buite te kyk en te beweeg (Kreminski 2014:67). Helland en Hjalmarson (2011:loc.1105) meen ook om 'n missionale spiritualiteit te vorm, is dissiplines soos gebed, vas, aanbidding, eredienste en koinonia baie belangrik. Maar dit is nie al nie: dit moet uiting kry in die fisiese en sosiale dimensies van menswees. Missionale spiritualiteit kweek gewoontes van betrokkenheid, eerder as 
onttrekking van die wêreld. Lidmate moet uitgedaag word om praktyke aan te leer wat hulle net so gereeld met die wêreld in kontak bring as die praktyke van hulle binnekamer (gebed en Woord). Beide hierdie gewoontes is nodig, inwaarts asook uitwaarts (Kreminski 2014:67). Die term inwaarts impliseer dat die Here die hart kom verander. Dit dwing uitwaarts na die wêreld toe.

Nuwe missionale bewegings begin altyd by die mense wat op die rand staan van hulle gemeenskap en sosiale klasse. Kok en Niemandt (2009:5) sê: 'A missional-incarnational spirituality and ethos result in the bringing of the presence of Christ into marginalised places or spaces where such presence is not recognised.'

\section{Spirituele dissipline 7: Die belangrikheid van aan tafel wees}

Wepener (2010:4) wys op die belangrikheid van die tafel en die maaltyd vir Jesus met sy inkarnasie op aarde. Die voorbeelde uit Lukas en Handelinge is beduidend oor hoe Jesus vir sy dissipels leer dat die maaltyd saam met mekaar van groot belang is. Die gemeenskap van gelowiges word in die Bybel die beste om die etenstafel uitgebeeld. Daar word ook talle voorbeelde gegee van hoe Jesus sy dissipels by die tafel leer terwyl die brood gebreek word, asook sy interaksie met ander groepe mense wanneer Hy by hulle gaan eet. Die rede hiervoor is om 'n spesifieke gemeenskap tussen gelowiges te kweek (Wepener 2010:4). Dit is 'n geleentheid om mekaar te vorm, beter te leer ken en om sake te oorbrug wat nodig is. As pelgrims op reis, is dit nodig om tye in te ruim om verhoudings om die tafel te bou.

Wepener (2010:4-5) gee verskillende voorbeelde.

\section{Dek die tafel by die kerk}

Wepener (2010:5) wys daarop dat die vierings van die nagmaal rondom die tafel 'n groot rol speel in die bou van verhoudings. Sweet (2014) argumenteer dat die diens by die tafel een van die belangrikste bedienings van die kerk is:

The Communion table in the sanctuary, and the table of communion in the fellowship hall - both are Lord's Tables that can turn the tables on real human concerns, such as poverty, persecution, and addictions. (p. 108)

Waar en wanneer Jesus ookal geëet het, het sy teenwoordigheid elke tafel in 'n altaar verander. Waar gelowiges rondom die tafel vergader, maak die teenwoordigheid van Christus dit elke keer 'n feesmaal waar gemeenskap met Hom gevier word. Die tafel was ook die veilige ruimte vir belangrike lewenslesse - by 15 van die 23 gelykenisse in Lukas word daar geëet (Sweet 2014:109-110).

\section{Dek die tafel by die huis}

Sweet (2014:82) sê dat daar niks so goed is vir 'n familie as om saam te eet nie. Dit is waar verhoudings gebou word en genesing tussen gesinslede plaasvind. Wepener (2010:5) is ook oortuig van die belang van gesinne wat gereeld saam eet.
Dit is noodsaaklik vir die vorming van verhoudings en die sosiale vorming van die hele gesin. Dit is ook 'n praktiese inoefening van gasvryheid. In die verlede het gesinne meer saam geëet en was huise oop vir die bure om saam te kom eet. Daar is sonder uitnodiging saam geëet en dit het die kerk soos liggaamsdele saamgesnoer. Diep verhoudings word gebou as daar saam geëet en gepraat word oor wat vir elkeen belangrik is. Sweet (2014:85) noem dit 'n onmisbare deel van gemeenskapsvorming.

Dit is ook 'n geleentheid waar ouers in hulle kinders se lewens betrokke kan wees - op alle gebiede van die lewe, onder andere ook op geestelike gebied. Gesinne is vandag baie divers en soms selfs disfunksioneel. Alhoewel daar baie druk is wat gesinslede van die tafel weghou, moet dit as een van die kosbaarste geleenthede gekoester word. Dit is 'n lewensbelangrike gesinsritme om tyd rondom 'n tafel saam deur te bring. Dit bind gesinslede aan mekaar en skep ruimte waar kos en lewenswysheid gedeel word (Sweet 2014:86).

\section{Dek die tafel in die wêreld}

In die vroeë kerk is daar groot geleenthede gereël vir die hele gemeenskap. Dit was geleenthede waar mense saam geëet en gekuier het. Dit het ure geduur, soms selfs dae lank (Sweet 2014:137). Hoewel die hedendaagse lewenswyse sulke feestye moeilik maak, behoort dit 'n belangrike prioriteit vir gemeentes te wees om saam brood te breek en verhoudings in die proses te versterk. Dit is 'n geleentheid om ware liefde aan naastes te wys en uit te reik na bure.

Uiteindelik gaan dit oor meer as fisiese brood - dit gaan oor die brood van die lewe wat gedeel word. Die tafel is oop - en daarom word bure en naastes uitgenooi om te kom aansit. In Sweet (2014:137) se woorde: 'I used to think hospitality was a lost art. Now I'm convinced it is a lost heart.'

Die tafel is die hart van ' $n$ gemeente se missionale gerigtheid en die ideale veilige ruimte vir besoekers en bure.

\section{Gevolgtrekking}

Die klem in geestelike vorming is meer op doen as op die deel van inligting. Hierdie studie het die belang van 'n trinitariese verstaan van spiritualiteit bevestig en die onmisbare aard van 'n missionale spiritualiteit vir geloofsgemeenskappe onderstreep. ' $n$ Lewe in die Drie-eenheid vorm die hart en lewe. Dit rig gelowiges om aan te sluit by dit wat God in verskillende kontekste aan die doen is. Hierdie soort spiritualiteit kan beskryf word as 'n missionale spiritualiteit wat die missionale aard en wese van die kerk steun en versterk. Dit lê in die wese en die hart van God en daarom moet dit ook in die agendas van kerkwees leef.

Die navorsing het 'n aantal praktiese geloofsgewoontes bespreek as energiepunte wat nuwe denke oor deelname aan die missio Dei kan versterk. Dit kom neer op die vorming van dít wat van God geglo word en dít wat mense in hulle harte begeer. Hierdie praktiese gewoontes kan dit versterk. 
Dit bring geloof en die alledaagse in nuwe roetines en ritmes bymekaar uit. Daar moet eerder nuwe gewoontes aangeleer word wat denke sal vernuwe, as wat denke verander word om gewoontes te beïnvloed. Daar is ook 'n ander perspektief: missionale kerkwees voed ook 'n lewenskragtige Christelike spiritualiteit! Om missionaal te wees, is veeleisend. Gekonfronteer met die nood en lyding in die wêreld, is om moeg en oorlaai te word altyd 'n moontlikheid vir die kerk.

Daarom sal 'n missionale kerk altyd inspirasie put uit Christelike dissiplines en die terugkeer na 'n lewenskragtige spiritualiteit om daardeur gevoed te word, energie te kry en visie te vernuwe. Daarna kan daar weer met nuwe entoesiasme in die wêreld inbeweeg word (Soos verduidelik deur Dr. W.C. de Klerk in 'n epos van 7 Junie 2018).

\section{Erkenning \\ Mededingende belange}

Die outeurs verklaar dat hulle geen finansiële of persoonlike verbintenis het met enige party wat hulle nadelig kon beïnvloed in die skryf van hierdie artikel nie.

\section{Outeurs bydrae}

P.C.P het die meerderheid van die navorsing gedoen as deel vir die MTh in Teologie in die Departement van Religiestudies. C.J.N. was toesighouer en het bygedra tot die ontwerp van die navorsing, gedeeltes van die finale kopie geskryf en het redigering en voorbereiding van die finale kopie gedoen.

\section{Literatuurverwysings}

Burger, C., 2017, 'Why we need the missional conversation in South Africa now', in C. Burger, F. Marais \& D. Mouton (eds.), Cultivating missional change. The future of missional churches and missional theology, pp. 20-34, Biblecor, Wellington.

Burns, S., 2017, 'Missional practises: You learn so as to live', in C. Burger, F. Marais \& D. Mouton (eds.), Cultivating missional change. The future of missional churches and missional theology, pp. 354-371, Biblecor, Wellington.

Cray, G., 2009, Mission-shaped church, Church House Publishing, Londen.

Ford, L. \& Hirsch, A., 2011, Right here, right now: Everyday mission for everyday people, Baker Books, Grand Rapids, MI.

Gornman, M.J., 2015, Becoming the gospel: Paul, participation and mission, Eerdmans, Grand Rapids, MI.

Harrison, M., 2017, 'Missional worship', in C. Burger, F. Marais \& D. Mouton (eds.), Cultivating missional change. The future of missional churches and missional theology, pp. 393-405, Biblecor, Wellington.

Hastings, R., 2012, Missional God, missional church: Hope for re-evangelizing the West, InterVarsity Press, Downers Grove, IL.

Helland, R. \& Hjalmarson, L., 2011, Missional spirituality: Embodying God's love from the inside out, InterVarsity Press, Downers Grove, IL.

Hendriks, H., 2007, 'Missional theology and social development', HTS Teologiese Studies 63(3), 999-1016. https://doi.org/10.4102/hts.v63i3.244

Hirsch, A. \& Altclass, D., 2009, The forgotten ways handbook: A practical guide for developing missional churches, Brazos Press, Grand Rapids, MI.

Howard, E.B., 2008, The Brazos introduction to Christian spirituality, Brazos Press, Grand Rapids.
Jackson, N., 2016, 'Ons is almal sendelinge', Kerkbode, viewed 28 Julie 2016, from http://kerkbode.christians.co.za/2016/03/16/ons-almal-sendelinge/

Janse van Rensburg, N., 2016, 'Gestuurdheid vra 'n paradigmaskuif', Kerkbode, viewed 28 Julie 2016, from http://kerkbode.christians.co.za/2016/02/19/gestuurdheidvra-n-paradigmaskuif/

Keifert, P.R., 2017, 'Missional theology as Trinitarian theology: A conversation with Patrick Keifert', in C. Burger, F. Marais \& D. Mouton (eds.), Cultivating missional change. The future of missional churches and missional theology, pp. 264-278, Biblecor, Wellington.

Kok, J. \& Niemandt, N., 2009, '(Re)discovering a missional-incarnational ethos', HTS Teologiese Studies 61(1), 7. https://doi.org/10.4102/hts.v65i1.274

Kreminski, K., 2014, Development of a spiritual formation model for the members of a missional church, ProQuest, Ann Arbor, Michigan, VA.

Marais, F., 2017, 'Missional formation and discipleship' in C. Burger, F. Marais \& D. Mouton (eds.), Cultivating missional change. The future of missional churches and missional theology, pp. 372-392, Biblecor, Wellington.

McNeal, R., 2009, Missional renaissance: Changing the scorecard for the church, Jossey-Bass, San Francisco, CA.

Mouton, D., 2017, 'Experiences with denominations in South Africa', in C. Burger, F. Marais \& D. Mouton (eds.), Cultivating missional change. The future of missional churches and missional theology, pp. 158-173, Biblecor, Wellington.

Nederduitse Gereformeerde Kerk (NGK), 2013, Raamwerkdokument oor die missionale aard en roeping van die NG Kerk, viewed 03 January 2015, from https://www.ngkerk. org.za/sites/all/themes/execute_responsive_theme/images/RAAMWERKDOKUMENT $\% 2000$ R $\% 20$ DIE $\% 20$ MISSIONALE $\% 20$ AARD $\% 20$ EN $\% 2$ ROEPING $\% 20$ VAN $\% 20$ DIE\%20NG\%20KERK.doc

Nicol, W., 2013, Gegryp deur Christus, Christelike Uitgewersmaatskappy, Vereeniging. Nicol, W., 2016, Oop vir die oomblik. Nader aan die hier en die nou met die Here, Bybelkor, Wellington.

Niemandt, C.J.P., 2016, 'Transformative spirituality and missional leadership', Mission Studies 33(2016), 85-103. https://doi.org/10.1163/15733831-12341435

Niemandt, N., 2007, Nuwe drome vir nuwe werklikhede, Lux Verbi, Wellington.

Niemandt, N., 2013, Nuwe leiers vir nuwe werklikhede, Christelike Uitgewersmaatskappy, Vereeniging.

Niemandt, N., 2014, 'Missionale kerk en missionale eredienste.'n Refleksie op Leonard Sweet se "Giving blood. A fresh paradigm for preaching"', Vir die Musiekleier 34(41), 6-20.

Ortberg, J., 2002, The life you've always wanted: Spiritual disciplines for ordinary people, Zondervan, Grand Rapids, MI.

Peterson, E.H., 2005, Christ plays in ten thousand places. A conversation in Spiritual Theology, Hodder and Stoughton, London.

Principe, W., 1983, 'Towards defining spirituality', Studies in Religion/Sciences Religieuses 12(2), 127-141. https://doi.org/10.1177/000842988301200201

Roxburgh, A.J., 2011, Missional. Joining God in the neigborhood, Baker Books, Grand Rapids, MI.

Sheldrake, P., 2007, A brief history of spirituality, Blackwell Publishing, Malden, MA.

Smith, J.K.A., 2009, Desiring the kingdom: Worship, worldview and cultural formation, Baker Academic, Grand Rapids, MI.

Smith, J.K.A., 2013, Imagining the kingdom: How worship works, Baker Academic, Grand Rapids, MI.

Smith, J.K.A., 2016, You are what you love: The spiritual power of habit, Baker Publishing, Grand Rapids, MI.

Sparks, P., Soerens, T. \& Friesen, D.J., 2014, The New Parish: How neighborhood churches are transforming mission, Discipleship and community, InterVarsity Press, Downers Grove, IL [Kindle Edition].

Sweet, L., 2014, From tablet to table: Where community is formed and identity is found, Navpress, Colorado Springs, CO.

Van Rensburg, J., 2018, 'Die roeping van 'n gemeente, ' $n$ prakties-teologiese ondersoek na die rol van AGS van SA gemeentes in die gemeenskap', PhD proefskrif, Universiteit van die Vrystaat, Bloemfontein.

Venter, R., 2015, 'A trinitarian approach to spirituality: Exploring the possibilities', HTS Teologiese Studies 71(1), 7. https://doi.org/10.4102/hts.v71i1.2952

Wepener, C., 2010, 'Snert: Ritual-liturgical measurements and recipes for social capital: Original research', Verbum et Ecclesia 31(1), 1-7. https://doi.org/10.4102/ ve.v31i1.407

Willard, D., 1996, The Spirit of the disciplines: Understanding how God changes lives, Hodder \& Stoughton, Londen.

World Council of Churches (WCC), 2013, Resource book, WCC 10th Assembly, Busan Geneva.

Zscheile, D.J., 2012, Cultivating sent communities. Missional spiritual formation, Eerdmans, Grand Rapids, MI. 